\title{
Spatial development of hydrological droughts in lake catchments
}

\author{
Malwina Kozek, Edmund Tomaszewski*
}

Department of Hydrology and Water Management, University of Łódź, 90-139 Łódź, Narutowicza 88, Poland, e-mail: malwina.kozek@geo.uni.lodz.pl; edmund.tomaszewski@geo.uni.lodz.pl (*corresponding author)

\begin{abstract}
In river-lake systems, reservoirs significantly affect the formation of water resources in the catchment by reducing the maximum flows and floods as well as increasing the low flows. In lake catchments, the pace of hydrological drought progression is usually slow. However, this phenomenon can be very extreme and destructive for water balance structure as a result of the very slow renewal rate of catchment resources. An estimation of hydrological drought development was conducted in the Biebrza river catchment $\left(6,900 \mathrm{~km}^{2}\right)$ on the basis of a daily discharge series for 18 water-gauge stations in the period 1982-2014. The number and location of the gauges allowed reliable results of the spatial pattern of drought to be obtained. The main objective of the research was the construction and assessment of the applicability of indicators which are estimators of drought spatial progression. Comparative analysis of four proposed indices led to two of them being recommended. These characteristics estimate the direction of drought development according to the stream network hierarchy, location of sub-catchments and the direction of river basin area increase. As a result, determinants of the spatial development of hydrological drought as well as its importance in the hydrographical structure were identified. Furthermore, the intensity of drought was evaluated and all investigated indices were applied to a time series analysis.
\end{abstract}

Key words: hydrological extremes, low flows, drought streamflow deficit, drought spatial analyses

\section{Introduction}

Lakes have a great impact on many hydrological processes and the structure of the water balance. In river-lake systems where a significant contribution of through- or outflowing lakes is observed, the process of runoff smoothing occurs (Bajkiewicz-Grabowska 2002). This is particularly connected with hydrological extremes - floods and droughts. The capacity of the temporarily unfilled volume of lake basins might reduce flood discharges in the catchment very effectively. In many cases, such retention will mitigate negative drought effects during water shortage periods. However, there are numerous determinants which can accelerate hydrological drought progression in a temporal and spatial pattern. The time structure of precipitation and its deficiency, evapotranspiration, groundwater retention or features of hydrogeological structure might be more important for low flow formation in lake-river systems than the shape and volume of lake basins. Moreover, over a long-term scale, drought streamflow deficit may be determined by factors whose activity is significantly stretched in time. Therefore, in the context of observed and predicted climatic changes, many lowland territo- ries and lake districts are partly affected or seriously put at risk of the negative consequences of a water deficit for public services, industry, agriculture and forestry as well as the degradation water ecosystems.

A shortage of catchment resources depends mainly on the intensity and extent of hydrological drought. In lake catchments, spatial availability of water resources is very diversified from the quantitative and genetic point of view. For example, small catchments with shallow lakes placed near watershed divides will show a very rapid reaction to hydrological drought progression, whereas in catchments with deep lakes, draining a few aquifer layers, streamflow drought will develop slowly (Tomaszewski 2012). Differentiation of the rate of these processes will result in various resource restrictions which are very important for water management. Therefore, the main goal of this paper is to create some of the characteristics of the spatial development of hydrological drought and its intensity. Assessment and interpretation of the proposed parameters will be based on the example of the lake catchment of the Biebrza river within which there are 18 water gauging stations that will allow an analysis of the spatial pattern of the investigated phenomenon to be performed. 


\section{Study area and data}

The research covered the Biebrza river catchment closed at the Burzyn water-gauge. The study area is located in the north-eastern part of Poland in the Masurian Lake District (Fig. 1). This is a young-glacial area with high number of post-glacial reservoirs, mainly chain and thaw lakes (Bajkiewicz-Grabowska 2002; Jóźwiak et al. 2019). In the lower part of the catchment there are old-glacial lakeless territories. The Biebrza Valley is located next to these areas (a sandy plain cut through by river valleys). The Biebrza river valley is an erosion channel that cuts through sandy-clayey sediments. It is a drainage base for shallow ground waters and surface waters. Groundwater alimentation by rivers in this area is mainly determined by waters of Quaternary formations as well as confined aquifers of cut through intermoraine layers. The Biebrza river valley is characterized by a high retention capacity, comparable to the capacity of large reservoirs. This results from the presence of an extensive wetland complex that stores up flood and meltwaters (Wassen 1992; Batelaan and Kuntohadi 2002; Mioduszewski et al. 2004; Anibas et. al 2012).

A typical component of the young-glacial landscape are lakes. In river-lake systems, reservoirs significantly affect the formation of the water resources in the catchment. Lakes are the base of drainage for surface and ground waters. They make river runoff less variable in the seasonal scale, i.a. by water storage in periods of runoff excess and by returning it during times of deficit (Bartnik 2005; Tokarczyk 2013). The river-lake network of the study area may be described as a spatial system of alternate existing ecosystems - rivers and lakes that are strictly connected to each other. Lakes have a significant impact on river flow quantity as well as its distribution and variability. Catchments with and without lakes are different in terms of annual runoff distribution. The regime of rivers flowing through lakes (e.g. the Jegrznia river, the Ełk, the Netta) might be characterized as simple, with one runoff maximum over the year - in the cold half-year. However, the hydrologi-

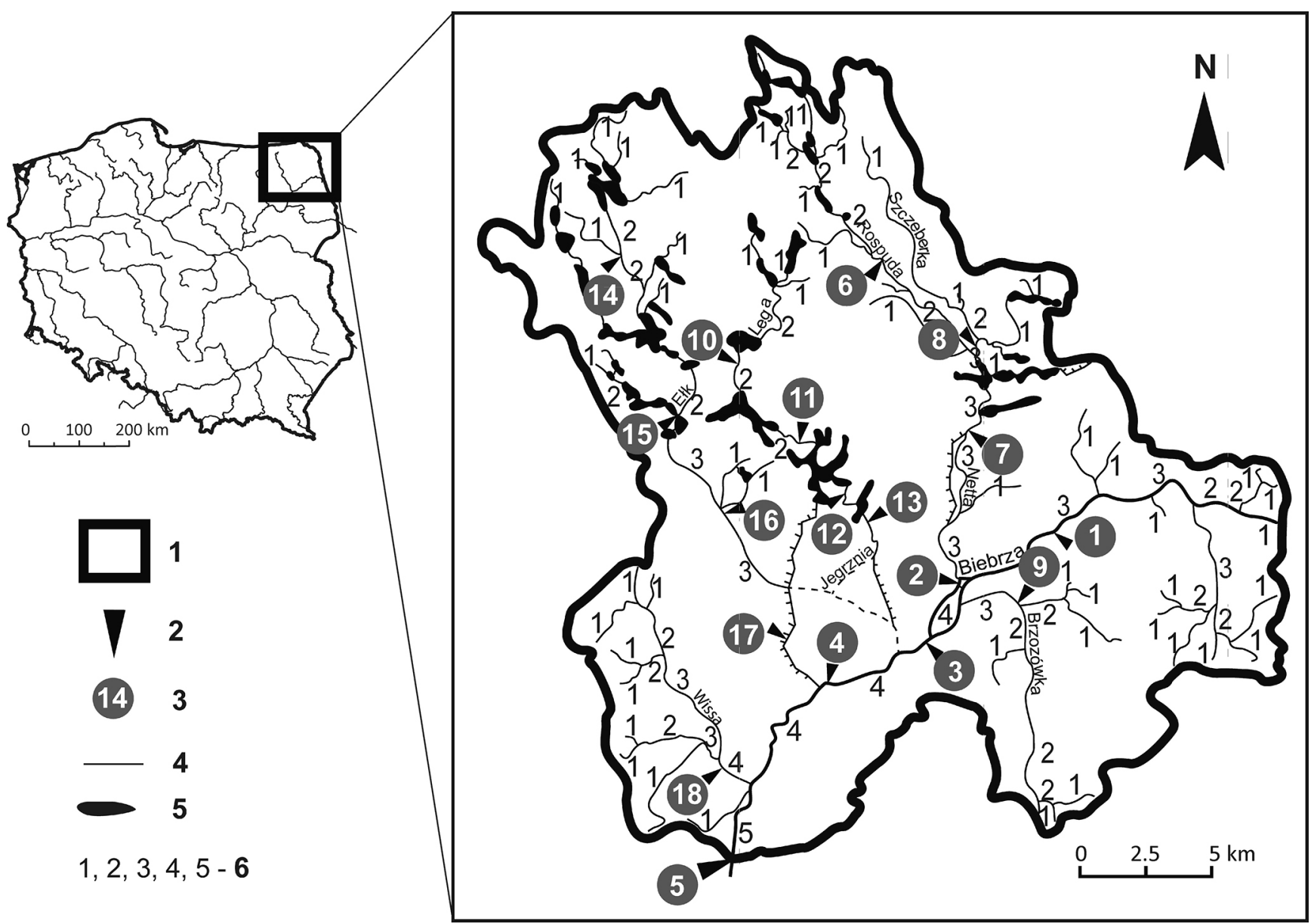

Fig. 1. The Biebrza river catchment to Burzyn water-gauge station

Explanations: 1 - location of the study area, 2 - water-gauge station, 3 - sub-catchment number (see Table 1), 4 - river, 5 - lake, 6 - orders of streams according to Strahler's classification. 
cal regime of rivers without such lakes (e.g. the Wissa river, the Brzozówka) is more complex, where spring and winter runoff maxima occur. The impact of a lake on river flow depends on the hydrological type of the reservoir. In the Biebrza river catchment there are lakes with outflow only where the river regime is strongly connected with the lake regime and runoff quantity depends on the dynamic resources of a lake and changes proportionally. There also exist reservoirs with river inflow and outflow. They play a significant role as runoff regulators, especially in the matter of flow stabilization (Bajkiewicz-Grabowska 2002).

The area of the investigated catchment is equal to $6,900 \mathrm{~km}^{2}$. Its river system is characterized by significant asymmetry. The right-bank part of the catchment is much better developed (75.5\%) than the left one (Byczkowski and Fal 2004). The hydrological regime of the Biebrza river was defined by Dynowska (1994) as nivo-pluvial. Total specific flow changes between $5 \mathrm{dm}^{3} \mathrm{~s}^{-1} \mathrm{~km}^{-2}$ in the upper part and $3 \mathrm{dm}^{3} \mathrm{~s}^{-1} \mathrm{~km}^{-2}$ in the lower part of the catchment. Base flow index reaches values in the range of 40-60\% (Jokiel 1994).

Assessment of the spatial direction of river low-flow development as well as the hydrological drought range required a hierarchical river system ordering application (Fig. 1). Drought streamflow deficit formation as well as direction and dynamics of low-flow progression depends on river location in the hydrographical structure (Tomaszewski 2012). The occurrence of river lowflows in the upper part of the catchment could cause their downstream progression which will indicate the spatial direction of hydrological drought in the in- vestigated area. Classification of stream network was made on the concept proposed by Strahler (1964). This is based on hierarchical stream ordering in the entire river system. The first order streams, in this method, are all streams that begin with source and end in a place of junction with another stream. The assumption is that the stream of number $r+1$ will appear when two streams of number $r$ join. Therefore, after the junction of two streams of number 1 , the stream of number 2 will appear, after the junction of two streams of number 2 number 3 will appear etc. However, when two streams of a different order number join, the higher number will be inherited by the stream after the junction. The hierarchical classification of the stream network in the Biebrza river catchment was done in accordance with this procedure. The maximum stream order reached number 5 (Fig. 1).

Basic hydrometrical material used for this research derived from 18 water-gauge stations serviced by the Polish Institute of Meteorology and Water Management (Table 1). Catchment areas closed by these water gauges were differentiated from 281 up to $6,900 \mathrm{~km}^{2}$, which allowed an assessment of the impact of alimentation area size on drought streamflow deficit formation to be made. Selected water-gauge stations were relatively evenly distributed over the whole catchment area. Five of them were located on the main river, one on the canal (Kanał Rudzki) and the others on the tributaries (Fig. 1). In the investigated group were catchments both with and without lakes, placed in initial as well as well-developed parts of the river system. In lakes with streams flowing through them, stations located directly

Table 1. List of water-gauge stations and sub-catchment characteristics

\begin{tabular}{|c|c|c|c|}
\hline No. & River - Water-gauge & Sub-catchment area (sq. km) & Sequence* $^{*}$ \\
\hline 1 & Biebrza - Sztabin & 846 & 1 \\
\hline 2 & Biebrza - Dębowo & 2,322 & 5 \\
\hline 3 & Biebrza - Stare Dolistowo & 3,064 & 7 \\
\hline 4 & Biebrza-Osowiec & 4,365 & 12 \\
\hline 5 & Biebrza - Burzyn & 6,900 & 18 \\
\hline 6 & Rospuda - Raczki & 281 & 2 \\
\hline 7 & Netta - Białobrzegi & 981 & 3 \\
\hline 8 & Szczebra - Szczeberka & 377 & 4 \\
\hline 9 & Brzozówka - Karpowicze & 650 & 6 \\
\hline 10 & Jegrznia - Chełchy & 394 & 8 \\
\hline 11 & Jegrznia - Kucze & 593 & 9 \\
\hline 12 & Jegrznia - Rajgród & 749 & 10 \\
\hline 13 & Jegrznia - Woźna Wieś & 852 & 11 \\
\hline 14 & Łaźna Struga - Małe Wronki & 258 & 13 \\
\hline 15 & Ełk - Ełk & 819 & 14 \\
\hline 16 & Ełk - Prostki & 1,156 & 15 \\
\hline 17 & Ełk (Kanał Rudzki) - Przechody & 1,456 & 16 \\
\hline 18 & Wissa - Czachy & 488 & 17 \\
\hline
\end{tabular}

*The sequence of sub-catchment numbering based on the principles given in the Hydrographical Division of Poland (IMGW 1983). 
upstream and downstream of the reservoir were taken into consideration. This allowed a more precise assessment of lake impact on the transformation of low-flow parameters. The group of selected catchments reflected the full spectrum of the physico-geographical conditions that determine the process of low-flow formation as well as hydrological drought progression in lake catchments. Thanks to this it was possible to investigate the development pace and movement velocity of lowflows in the river network as well as the evolution of direction, range and severity of hydrological droughts in river-lake systems.

The input data were a daily discharge series from the period 1982-2014. The investigated multi-year period was characterized by high dynamics of hydrometeorological conditions. On the basis of precipitation data for this period it was estimated that the lowest sums of precipitation occurred at the end of the 1980s and the beginning of 1990s as well as at the beginning of the 21 st century, which determined prolonged and severe hydrological droughts. The highest rainfalls by contrast were observed at the beginning and the end of the investigated period which resulted in serious floods.

\section{Methods}

\section{Identification of hydrological drought}

Hydrological drought is the most enhanced form of this part of the hydrological cycle which is determined by supply shortages related to the distribution of precipitation or snow and ice retention. The early phases are determined by the development of meteorological and soil drought. The lack of rainfall alimentation in connection with strong ground over-desiccation prevents the effective recharge of groundwater resources which leads to cutting aquifers off from the water supply. However, aquifer storage is continuously drained by rivers, lakes and springs which results in a groundwater table recession (groundwater low-flow) and after a little delay in the recession of surface water which is usually in a hydraulic connection to groundwater (surface water low-flow) (Hisdal et al. 2001, 2004; Tomaszewski 2012).

River low-flow is taken as a symptom of hydrological drought (Strzebońska-Ratomska 1994). It occurs in the period of low flows in riverbeds caused by a long-term lack of precipitation or frost appearance (Dębski 1970; Smakhtin 2001; Kaznowska 2012). An unambiguous definition of low-flow based on its origin does not exist. Therefore, it is usually defined on the basis of a discharge threshold level and event duration. The second-order main flows, periodic flows from the flow duration curve or conventional flows such as environmental and minimum navigable flows might be assumed as truncation levels. As a result, the low-flow is a period in which runoff is lower than the defined threshold level (Yevjevich 1967; Ozga-Zielińska 1990; Hisdal et al. 2004; Tomaszewski 2011). In the temporal aspect it is assumed to define the minimum duration of low-flow which proves its significance. In the literature, a period from a few to several days is accepted as a described duration (Kaznowska 2006; Tomaszewski 2012; Tokarczyk 2013). Due to the lack of objective premises that allow the minimum low-flow duration to be determined, at this stage the parameters are arbitrarily adopted and depend on the individual hydrological features of the studied catchments.

In this study, low-flows were identified on the basis of a statistical criterion assuming the 70th percentile from the flow duration curve as a threshold level. This was determined on the basis of a series of daily discharges from a multi-year period. Additionally, the 7 -day period was taken as the minimum low-flow duration and some low-flow episodes separated by an interruption lasting no longer than 3 days were analysed as inherently homogeneous events, combining their duration and volume. Based on the above criteria, the identification of low-flows was made and their basic parameters such as duration and drought streamflow deficit volume were estimated (Fig. 2).

Hydrological drought determines shortages of ground and surface water, therefore river low-flow is considered as a good indicator of drought development (Tokarczyk 2013). As a result, during the identification of hydrological droughts, some assumptions were made. At first, the occurrence of river low-flow is the result of the appearance of hydrological drought. According to this assumption, the beginning of the low-flow in the river means the beginning of the hydrological drought while the end of the river low-flow is associated with drought termination. If the low-flow was recorded at several water-gauge stations at the same time, the beginning of drought was related to the begin-

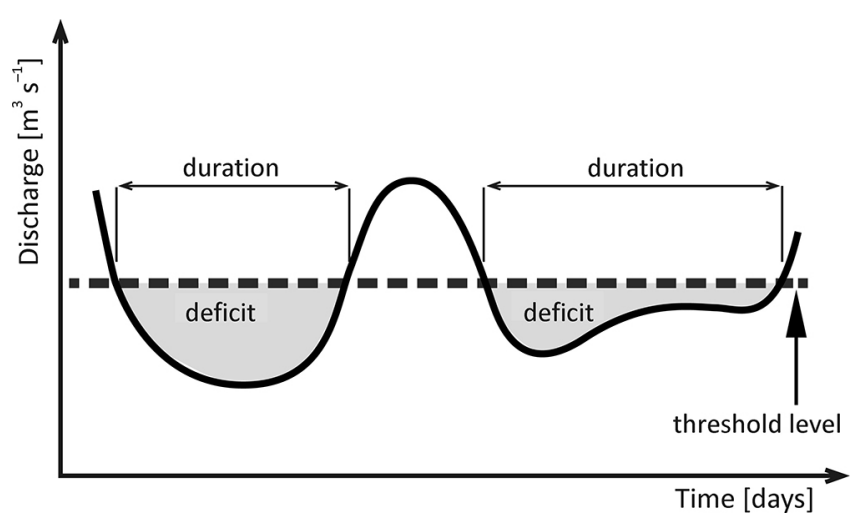

Fig. 2. Basic parameters of a river low-flow 


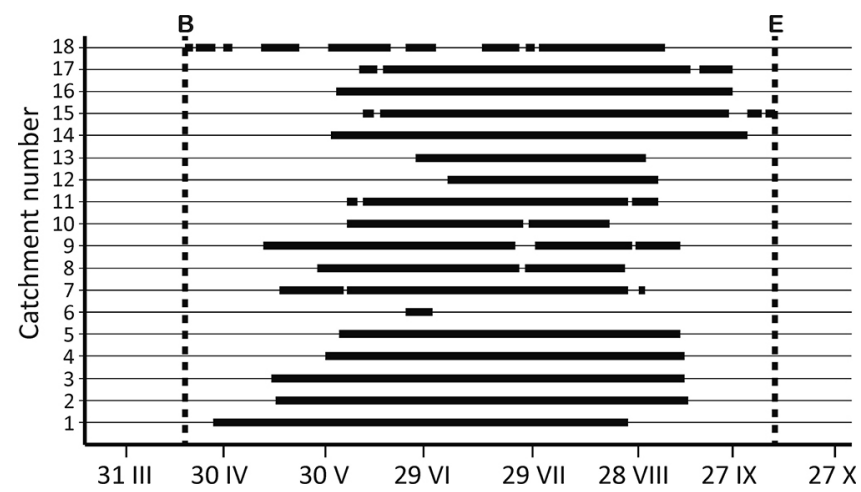

Fig. 3. Example of the course of hydrological drought in the Biebrza river catchment in 1990

Explanations: B - beginning of the drought, $\mathrm{E}$ - end of drought, black lines - low-flow occurrence; sub-catchment numbers correspond with these in Table 1.

ning of the first low-flow and the end of drought - with the end of the last low-flow event (Fig. 3). It was necessary to make another assumption, due to fact that lowflows occur asynchronously in rivers and hydrological droughts may develop in several phases. This assumes that droughts are separate, individual events if the intervals between them exceed 30 days.

In accordance with the adopted assumptions 47 hydrological droughts were identified in the Biebrza river catchment in the period 1982-2014. They lasted from 8 to 623 days. However, it was necessary to select the events which were significant from a spatial point of view. For this purpose, the drought range index (DRI) was used. This indicates what part of the catchment was covered by drought in its maximum stage of development. It is determined by computing the percentage contribution of sub-catchment areas covered by drought in the entire catchment area (Kozek and Tomaszewski 2018):

$$
D R I=\left(\sum_{\mathrm{i}=1}^{\mathrm{N}} A D_{i} / \sum_{\mathrm{i}=1}^{\mathrm{N}} A_{i}\right) \times 100 \%
$$

where: $D R I$ - Drought Range Index [\%], $A D_{i}$ - the sum of sub-catchment areas covered by the hydrological drought $\left[\mathrm{km}^{2}\right], A_{i}$ - the sum of all sub-catchment areas $\left[\mathrm{km}^{2}\right], N$ - number of sub-catchments.

The drought range index (DRI) was computed for all 47 identified hydrological droughts (Fig. 4). It ranged from 2.26 to $100 \%$. The low value of this index obviously means that hydrological drought is not very spatially significant. Droughts of the smallest range covered one or two sub-catchments and lasted from 8 to 30 days. The drought from 1986 was characterized by wider range (about $27 \%$ ). It affected almost $1 / 3$ of the catchment area, but above this value a quick increase of DRI is observed (Fig. 4). Therefore, it was assumed that drought was significant from a spatial point of view if

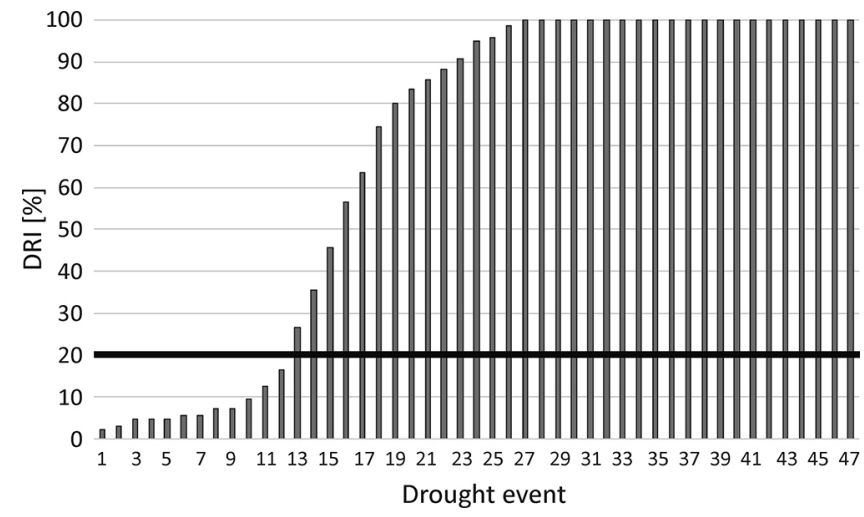

Fig. 4. Distribution of Drought Range Index in non-decreasing order (horizontal line marks a significance level of hydrological drought from a spatial point of view

it covered more than $20 \%$ of the catchment area. Based on the above criterion, 35 spatially significant droughts were selected.

\section{Characteristics of hydrological drought development}

The main objective of the research was the construction and assessment of the applicability of indicators that are estimators of drought spatial development. Two such indicators have been proposed - drought range index (DRI) and drought development index (DDI). The first has already been presented. It illustrates the degree of catchment coverage by hydrological drought. In turn, the DDI index estimates the increase or decrease of studied phenomenon with the rise of the catchment area. Due to the very poor recognition of the hydrological drought pattern and spatial dynamics in a catchment, especially in lake catchments, several DDI index approaches were proposed. They vary in the spatial reference scheme. As a result, four genetic approaches were applied which relate to the hierarchy of streams and sub-catchments, as well as the increase of the river basin area.

The first approach assesses the development of hydrological drought in zones where borders are determined by watershed divides running through arbitrarily adopted nodal water gauges. The zones are ordered according to the flow direction downstream of the catchment. The direction and range of hydrological drought development is examined in relation to the determined zones. The Biebrza river catchment was divided into four such zones (Fig. 5A). Two extreme zones covered the headwater and outlet parts of the studied catchment. The middle zones consisted mainly of tributary and main river catchments inside which the largest contribution of lakes was observed.

In order to illustrate the contribution of hydrological drought in particular catchment zones, a drought range 
graph was constructed (Fig. 6A). This graph was created by setting the areas of particular zones on the abscissa axis and the drought contribution in these zones on the ordinate axis. The presented graph indicates that the largest contribution of hydrological drought from $1987 / 1988$ covered the upper and middle parts of the studied area. The drought did not occur in the lowest part of catchment. This graph is strictly related to the DRI index. The value of the drought range index can be determined thanks to the estimation of the contri- bution of the shaded area $\left(F_{i}\right)$ in the area of the entire rectangle $\left(F_{i}+F_{p}\right)$.

The problem of hydrological drought development in the catchment was presented on the basis of the graph of cumulative increase of drought contribution (Fig. $6 \mathrm{~B})$. In this case, the areas of zones were also marked on the abscissa axis. However, the cumulative values of drought contribution in particular zones were put on the ordinate axis. It can be assumed that the hydrological drought developing in the upper part of catchment
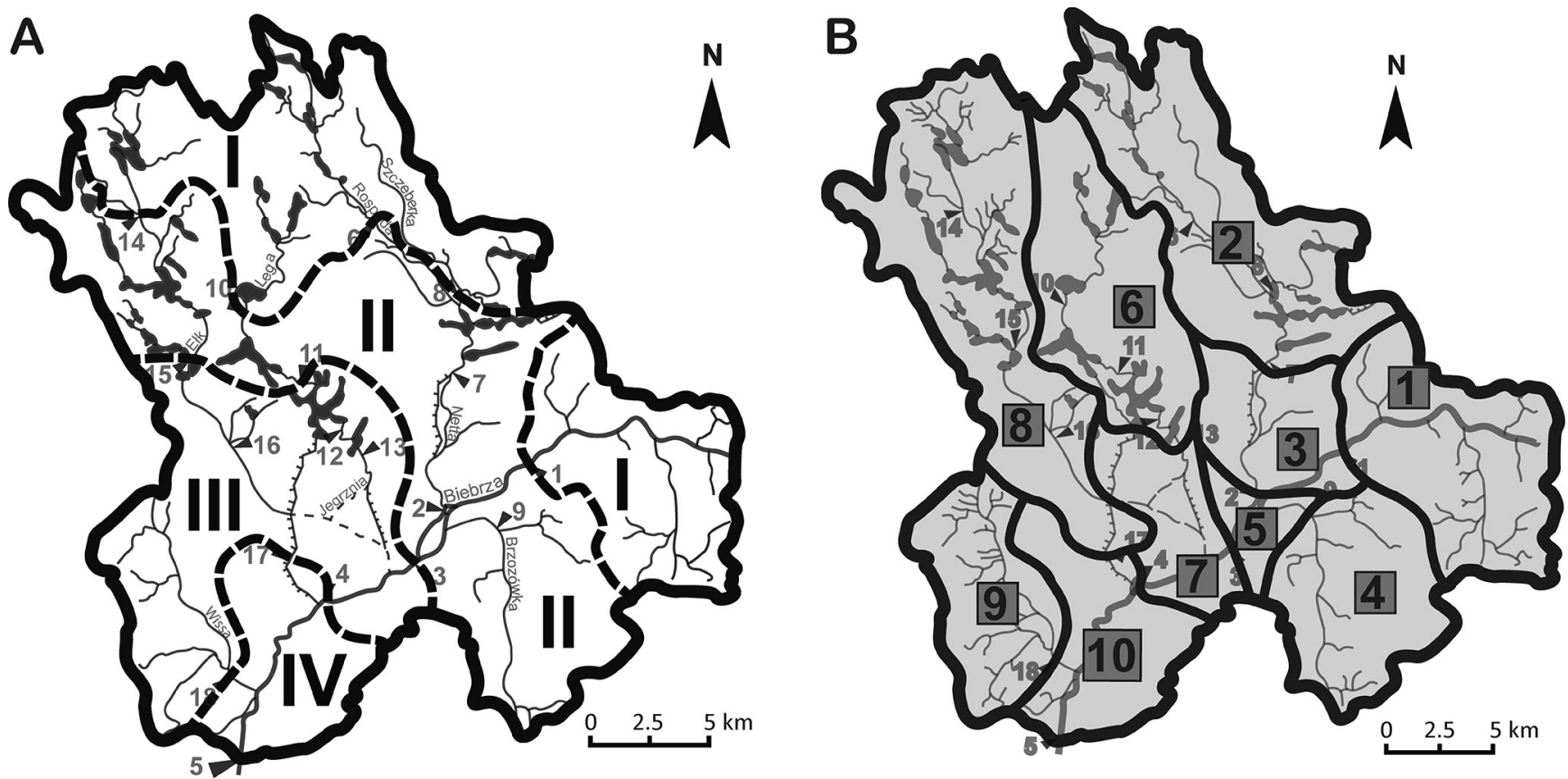

Fig. 5. Partition of the Biebrza river basin into zones (I-IV) along the main stream (A) and into the sub-catchments (numbers 1-10) (B)
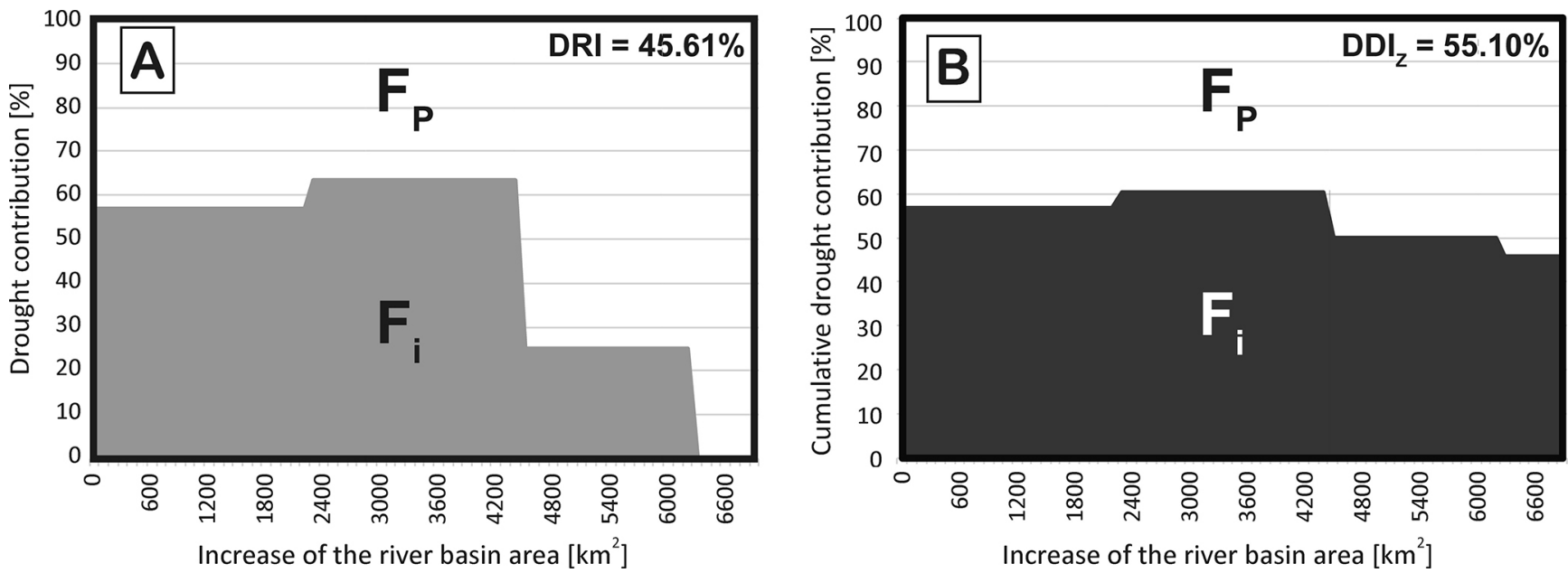

Fig. 6. Drought range (A) and drought range cumulative (B) plots illustrating hydrological drought development in the Biebrza river basin in 1987/1988 according to its division into zones

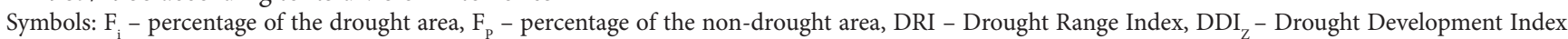
based on basin division into zones 
is more dangerous because there are relatively smaller water resources there and the resulting low-flows may move down the river system. The drought contributions in the upper and middle parts of the catchment in Figures $6 \mathrm{~B}$ and $6 \mathrm{~A}$ are similar, however, the drought recession in the lower part is less due to the assumption that drought from the upper part of catchment can affect the lower one.

On the basis of the graph of cumulative increase of drought contribution, it was possible to estimate the drought development index based on the catchment division into zones along the course of main river $\left(\mathrm{DDI}_{\mathrm{Z}}\right)$. This was done by estimating the contribution of the resultant figure area $\left(F_{i}\right)$ in the area of the entire rectangle $\left(F_{i}+F_{p}\right)$ (Fig. 6B):

$$
D D I_{Z}=\left[F_{i} /\left(F_{i}+F_{p}\right)\right] \times 100 \%
$$

where: $D D I_{Z}$ - Drought Development Index based on catchment division into zones along the course of the main river [\%], $F_{i}$ - area of the figure which presents the hydrological drought development, $F_{i}+F_{p}$ - total area of the rectangle with a base equal to the catchment area, and a height equal to $100 \%$ of drought contribution.

The value of $\mathrm{DDI}_{z}$ depends on the range and direction of hydrological drought development in the catchment. If the studied phenomenon does not cover the entire catchment area then it is very important to determine in which part of it drought occurs. If it develops in the upper part, it will have a higher $\mathrm{DDI}_{Z}$ than if the same drought area develops in the lower part. This is a result of the assumption that drought in the upper part is potentially more dangerous in the matter of resource depletion and drought development direction.

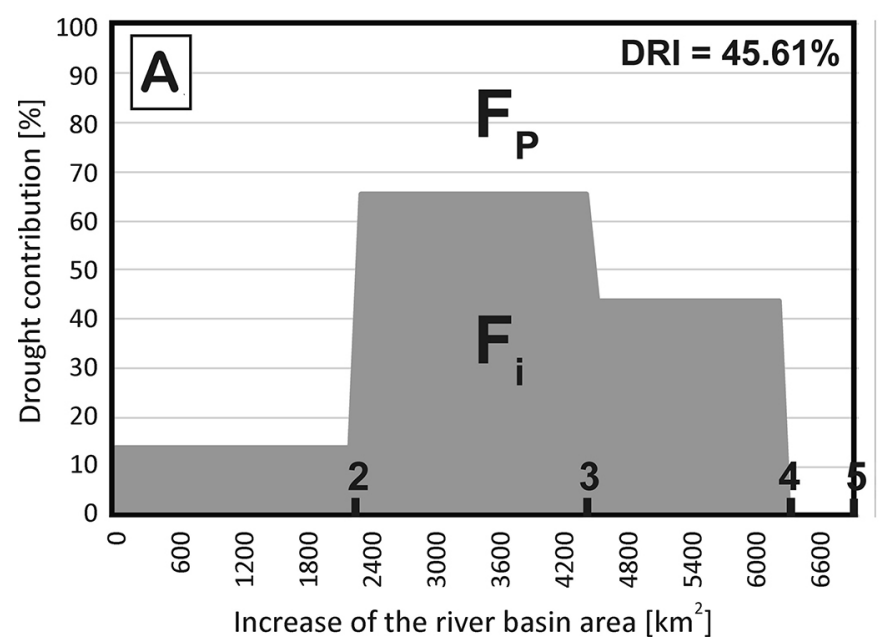

In the second approach, hydrological drought development was assessed on the basis of Strahler's stream order classification. At first, all order numbers of the streams were identified (Fig. 1). Then estimated numbers were assigned to water-gauge stations, depending on their location; if the gauge was located on the 2nd order stream, it also inherited the 2 nd order. In the investigated catchment there were four groups of gauges numbered from 2 to 5 . For the catchments closed by water gauges of the same order, the sum of areas and spatial drought contribution were estimated. On this basis, graphs of drought range and cumulative increase of drought contribution were constructed (Fig. 7) which allowed the DDI index to be estimated, analogically to the idea presented in formula (2). The spatial drought progression in this approach depends on the hierarchical location of the water gauge (affected by drought) in the river system. If drought occurs in catchments of 1 st order streams, it is very likely that it will also develop in catchments of higher numbers. The graph of the drought range in 1987/1988 indicates the largest contribution in catchments of 3 rd order streams which refers to the middle part of the studied catchment (Fig. 7A). If one compares cumulative graphs for "zones" and "Sthraler's" approaches in the general downstream direction (Fig 6B and 7B), significant differences can be noticed. In the first approach, the recession of the drought with the increase of catchment size is observed, whereas in the second approach the increase of drought contribution along a rising stream order is clearly noticeable. As a result, the DDI indices differ as well. A lower percentage of $\mathrm{DDI}_{\mathrm{S}}$ should be connected with a small drought contribution in the catchments of headwater streams which, according to

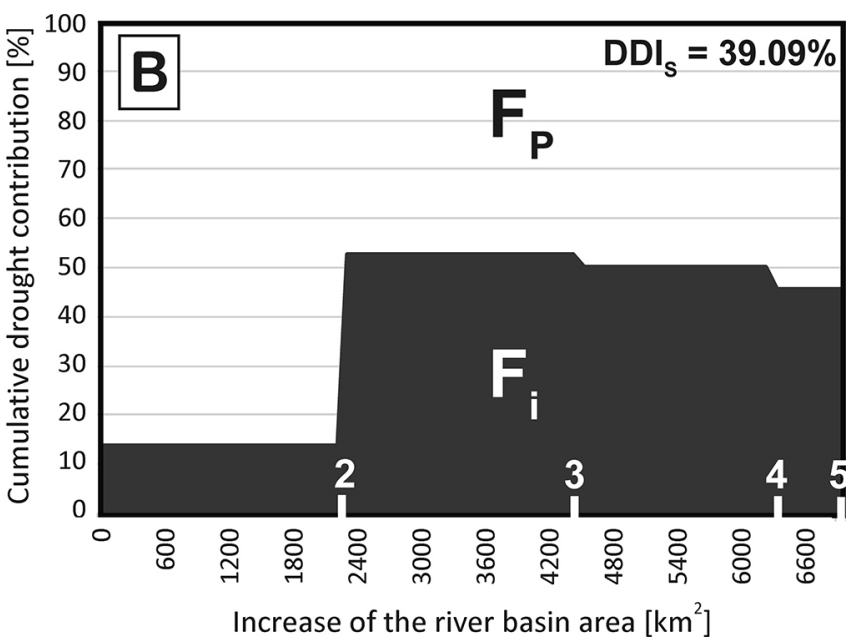

Fig. 7. Plots illustrating hydrological drought development in the Biebrza river basin in 1987/1988 according to basin division into catchments of the same orders based on Strahler's method (numbers on the $\mathrm{x}$-axis) $\mathrm{DDI}_{\mathrm{S}}$ - Drought Development Index based on Strahler's catchments, the other symbols as in Fig. 6. 
the assumptions made, mitigate the influence on downstream drought progression.

In the third approach, the hydrological drought development was assessed according to the sub-catchments ordered along the river course. The Biebrza river catchment was divided into 10 sub-catchments closed by the water-gauges on the main river and its direct tributaries (Fig. 5B). Drought range and contribution in delimited space units is illustrated in Figure 8A. Maximum drought contribution is observed in the upper sub-catchments, whereas the lowest part is free or covered by only a very small percentage. When analysing the course of the studied phenomenon one can notice its recession with the increase of consecutive subcatchments (Fig. 8B). Although similar recession is also observed in the first approach (Fig. 6B), the drought

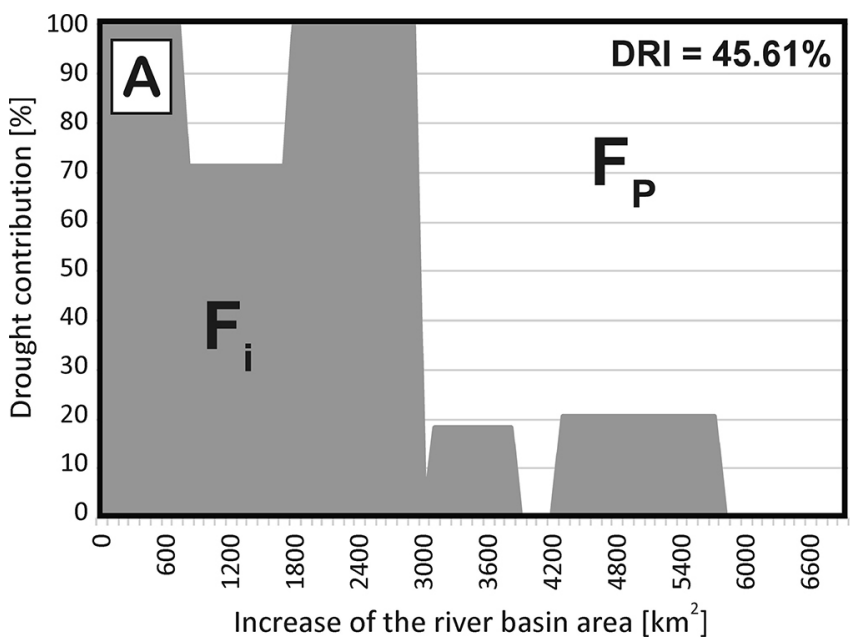

courses and the $\mathrm{DDI}_{\mathrm{z} / \mathrm{C}}$ indices differ significantly, which is mainly caused by the different levels of space unit generalization (4 zones vs 10 sub-catchments).

The last proposed approach assesses the development of drought according to the increase of the river basin area. This method evaluates the drought contribution in all possible sub-catchments, determined for each water-gauge station. Finally, 18 sub-catchments were estimated. The sequence of their numbering (Table 1) was based on the principles given in the Hydrographical Division of Poland (IMGW 1983). The graph of drought range differs significantly from the others. This is because single elementary units are used for estimation of drought contribution. As a result, on the range graph only $0 \%$ or $100 \%$ segments may appear (Fig. 9A). Irregularity in the course of cumulative

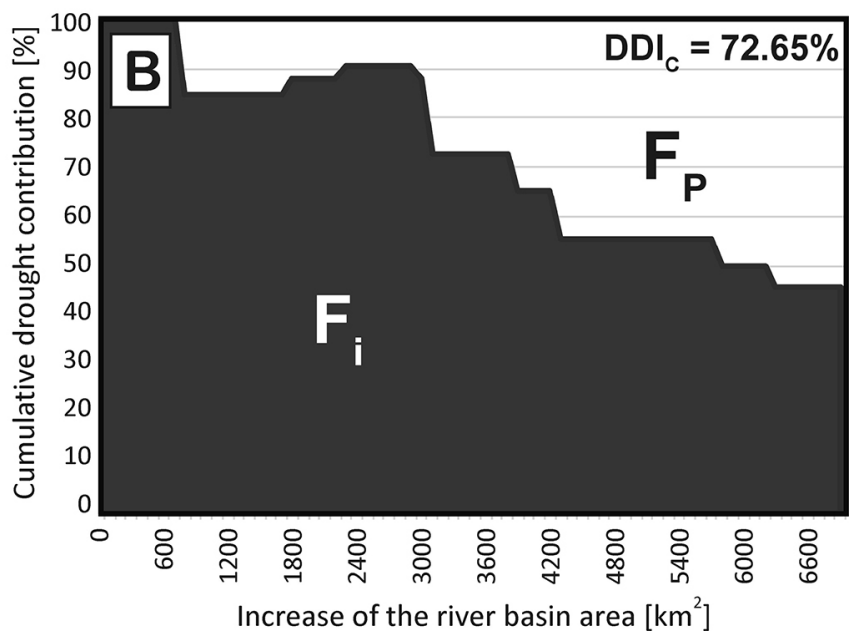

Fig. 8. Plots illustrating hydrological drought development in the Biebrza river basin in 1987/1988 according to its division into sub-catchments

$\mathrm{DDI}_{\mathrm{C}}$ - Drought Development Index based on basin division into sub-catchments, the other symbols as in Fig. 6.
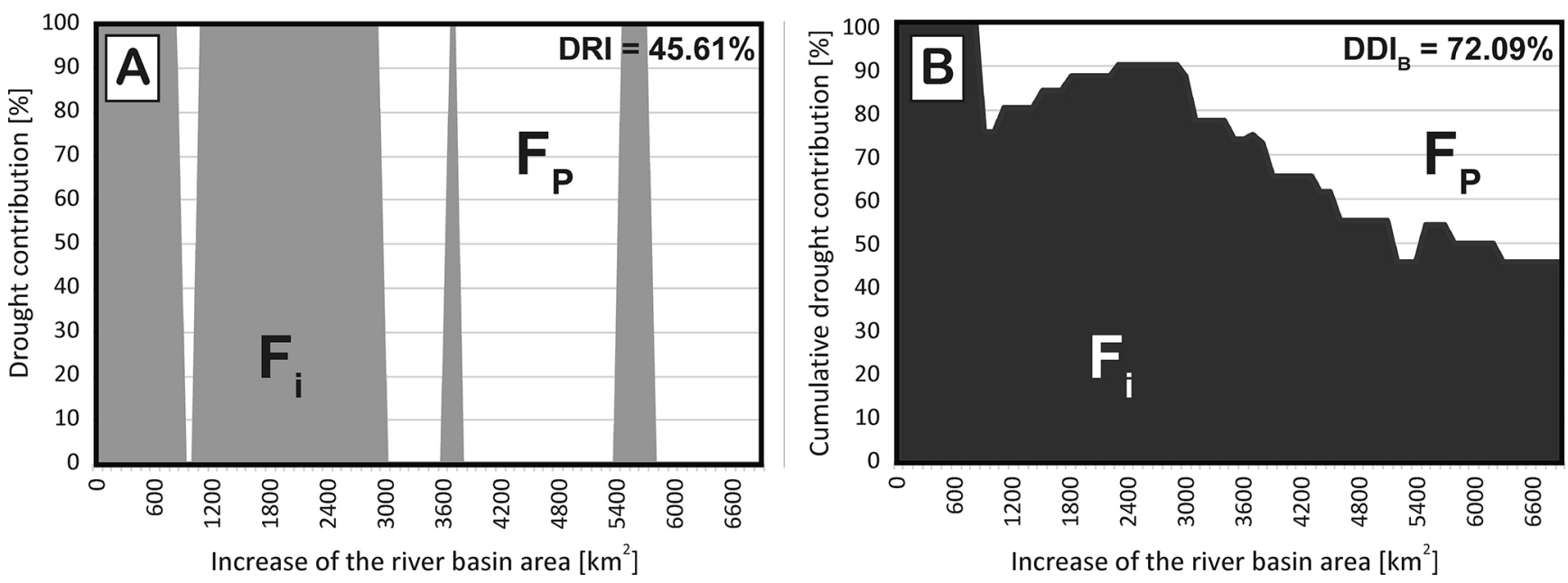

Fig. 9. Plots illustrating hydrological drought development in the Biebrza river basin in 1987/1988 according to the increase of the river basin area

$\mathrm{DDI}_{\mathrm{B}}-$ Drought Development Index based on the increase of the river basin area, the other symbols as in Fig. 6 . 
drought contribution is also determined by the specificity of elementary units (Fig. 9B).

Finally, the characteristic of hydrological drought intensity was evaluated. The relative drought streamflow deficit (RSD) was considered as a good estimator of the drought severity and it was estimated for each identified low-flow event according to the formula (Tomaszewski 2012):

$$
R S D=\left(V_{n} / V_{\max }\right) \times 100 \%
$$

where: $R S D$ - Relative Drought Streamflow Deficit [\%], $V_{n}$ - drought streamflow deficit volume $\left[\mathrm{m}^{3}\right], V_{\max }-$ maximum possible streamflow deficit volume during the studied period, i.e. when discharge value equals 0 $\left[\mathrm{m}^{3}\right]$.

This characteristic valorises not only the intensity of streamflow deficit, but also indicates the degree of depletion of catchment resources which remain in a hydraulic connection with the low flows. It should be noted that an index value equal to $100 \%$ denotes a lack of discharge in the riverbed. As the results are located in the percent scale, the presented measure could be applied as an indicator of the severity of hydrological drought. However, the RSD index refers to the river low-flows only. Therefore, to estimate the severity of drought, the hydrological drought severity index (DSI) was used. It was computed using a weighted average of RSD for every catchment (water-gauge), where the catchment area size was the weight (Kozek and Tomaszewski 2018):

$$
D S I=\sum_{\mathrm{i}=1}^{\mathrm{N}}\left(R S D_{i} \times A_{i}\right) / \sum_{\mathrm{i}=1}^{\mathrm{N}} A_{i}
$$

where: DSI - Drought Severity Index [\%], $R S D_{i}$ - Relative Drought Streamfow Deficit in the catchment $i$ [\%], $A_{i}$ - area of the sub-catchment $i\left[\mathrm{~km}^{2}\right], N$ - number of sub-catchments where low-flows have occurred.

The presented index evaluates the progress of hydrological drought in the entire studied catchment. Its values range from 0 to $100 \%$ where severity level changes proportionally to percentage. Application of this characteristic will be useful in the assessment of relationships between range, progression and severity of hydrological drought and could provide an effective support in complex analyses of water shortage periods.

\section{Results and discussion}

For all identified hydrological drought events in the Biebrza river catchment, characteristics involving drought duration, range and severity indices as well as the drought development index based on all 4 proposed approaches were estimated (Table 2). The assessment of features and the interpretative scope of the estimated indices was conducted based on the example of 3 selected hydrological drought events. Droughts selected for analysis differed as much as possible in terms of dynamics and spatial range. None of them covered the entire catchment area. They are characterized by different duration, dynamics of development and season of occurrence. As a result, it was possible to assess a wide spectrum of conditions that form hydrological drought
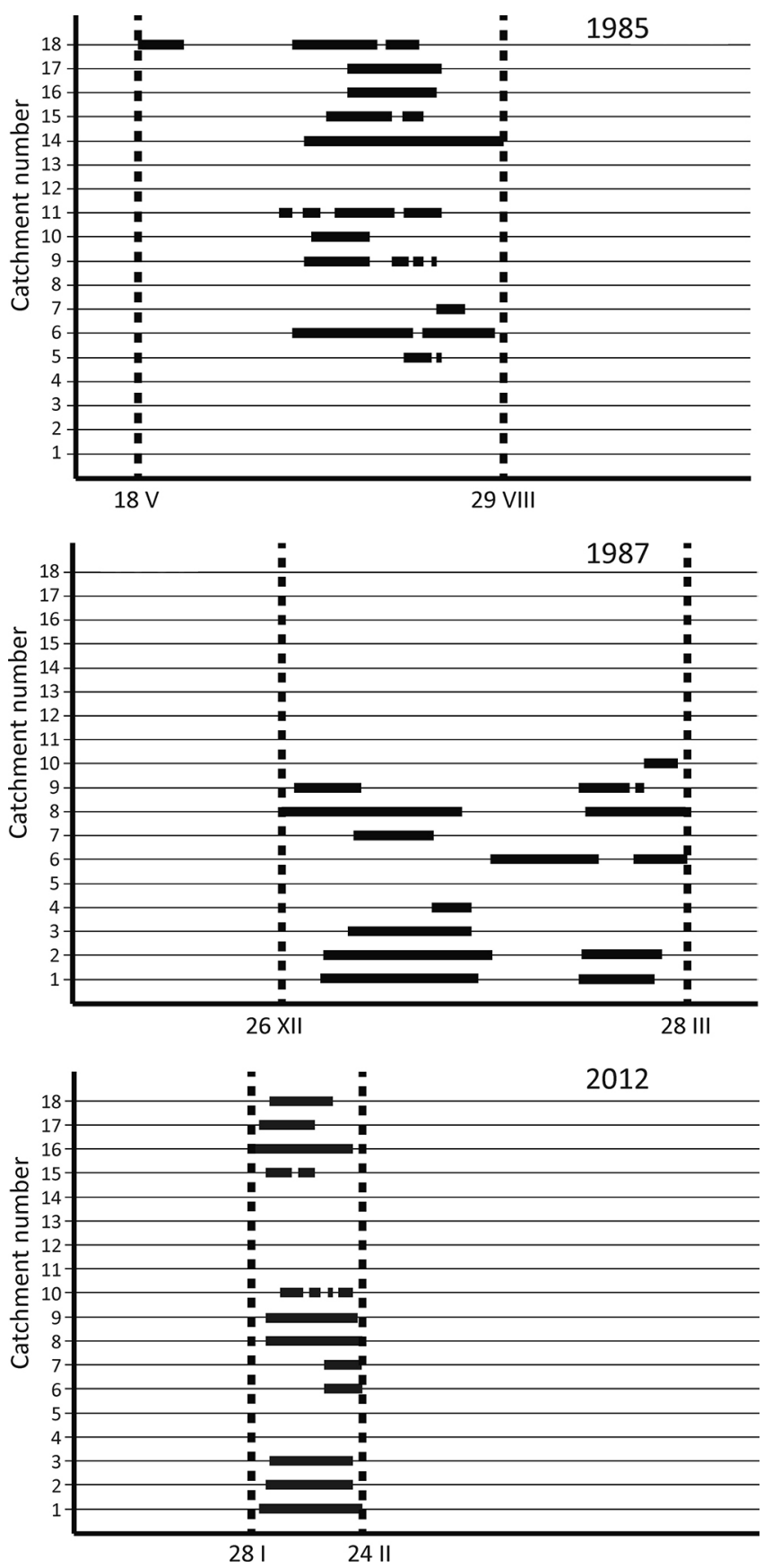

Fig. 10. The course of hydrological droughts in 1985, 1987 and 2012. All symbols as in Fig. 3 
in lake catchments. Selected events came from 1985, 1987 and 2012 (Fig. 10).

Droughts from 1985 and 1987 showed a similar duration (about three months), while the drought from 2012 was significantly shorter (it lasted less than one month) (Table 2). All of three events were characterized by a moderate intensity of water shortage because the drought severity index DSI did not exceed 13\%. The first of the analysed droughts developed in the springsummer period, the second one in winter-spring time, while the third drought occurred in winter only. Each of the selected events covered a different part of the catchment which allowed us to analyse the direction of their development according to hierarchy of stream network, location of sub-catchments and the direction of increase of the river basin area. The drought from 1985 occurred in the lower and middle part of the Biebrza river catchment, the second drought (1987) covered the upper part of the investigated area while the drought form 2012 covered the whole upper part and locally appeared in the middle and lower part of the catchment (Fig. 11).

The drought range graphs (DRI) in the spatial units delimited in particular research approaches (Fig. 12) reflect their spatial range (Fig. 11). In the drought event from 1985, the lower part of the catchment was strongly exposed in all the presented approaches because it was completely covered by drought. In the other cases the upper part of catchment was dominated by drought. Moreover, the significant differentiation of drought

Table 2. Characteristics of significant hydrological droughts in the Biebrza river catchment in the years 1982-2014

\begin{tabular}{|c|c|c|c|c|c|c|c|c|}
\hline No. & Period & $D_{t}$ & DRI & $\mathrm{DDI}_{\mathrm{z}}$ & $\mathrm{DDI}_{\mathrm{s}}$ & $\mathrm{DDI}_{\mathrm{C}}$ & $\mathrm{DDI}_{\mathrm{B}}$ & DSI \\
\hline 1 & 03 JUN 1982-15 DEC 1982 & 196 & 100.0 & 100.0 & 100.0 & 100.0 & 100.0 & 24.2 \\
\hline 2 & 01 JUN 1983-30 DEC 1983 & 213 & 100.0 & 100.0 & 100.0 & 100.0 & 100.0 & 28.4 \\
\hline 3 & 16 FEB1984-23 NOV 1984 & 282 & 100.0 & 100.0 & 100.0 & 100.0 & 100.0 & 18.6 \\
\hline 4 & 04 JAN 1985-28 MAR 1985 & 84 & 80.0 & 82.6 & 77.3 & 90.6 & 92.1 & 14.8 \\
\hline 5 & 18 MAY 1985-14 AUG 1985 & 104 & 63.5 & 55.0 & 68.0 & 41.3 & 40.6 & 9.3 \\
\hline 6 & 14 FEB 1986-07 MAR 1986 & 22 & 26.6 & 25.6 & 20.1 & 28.0 & 26.5 & 1.5 \\
\hline 7 & 18 JUN 1986-26 OCT 1986 & 131 & 100.0 & 100.0 & 100 & 100.0 & 100.0 & 29.6 \\
\hline 8 & 26 DEC 1986-28 MAR 1987 & 93 & 56.6 & 74.8 & 61.4 & 84.5 & 86.9 & 5.9 \\
\hline 9 & 24 MAY 1987-20 NOV 1987 & 181 & 45.6 & 55.1 & 39.1 & 72.7 & 72.1 & 5.2 \\
\hline 10 & 17 JUL 1988-21 DEC 1988 & 159 & 90.8 & 88.4 & 84.6 & 88.1 & 88.4 & 9.7 \\
\hline 11 & 17 MAY 1989-25 OCT 1989 & 162 & 100.0 & 100.0 & 100.0 & 100.0 & 100.0 & 26.0 \\
\hline 12 & 09 APR 1990-07 OCT 1990 & 182 & 100.0 & 100.0 & 100.0 & 100.0 & 100.0 & 25.2 \\
\hline 13 & 09 MAY 1991-22 MAR 1992 & 280 & 100.0 & 100.0 & 100.0 & 100.0 & 100.0 & 27.7 \\
\hline 14 & 22 MAY 1992-01 DEC 1992 & 195 & 100.0 & 100.0 & 100.0 & 100.0 & 100.0 & 40.4 \\
\hline 15 & 30 APR 1993-18 DEC 1993 & 233 & 100.0 & 100.0 & 100.0 & 100.0 & 100.0 & 21.1 \\
\hline 16 & 17 JUN 1994-24 NOV 1994 & 161 & 100.0 & 100.0 & 100.0 & 100.0 & 100.0 & 36.7 \\
\hline 17 & 30 MAY 1995-01 NOV 1995 & 156 & 100.0 & 100.0 & 100.0 & 100.0 & 100.0 & 24.1 \\
\hline 18 & 14 DEC 1995-10 APR 1996 & 118 & 98.5 & 98.6 & 89.5 & 97.3 & 97.8 & 14.3 \\
\hline 19 & 01 JUN 1996-02 JAN 1998 & 582 & 100.0 & 100.0 & 100.0 & 100.0 & 100.0 & 24.9 \\
\hline 20 & 23 MAY 1998-18 DEC 1998 & 210 & 88.1 & 85.6 & 90.1 & 95.1 & 95.2 & 10.3 \\
\hline 21 & 04 JUL 1999-28 JAN 2000 & 210 & 100.0 & 100.0 & 100.0 & 100.0 & 100.0 & 23.1 \\
\hline 22 & 26 APR 2000-10 MAR 2001 & 320 & 100.0 & 100.0 & 100.0 & 100.0 & 100.0 & 24.1 \\
\hline 23 & 06 MAY 2001-22 SEP 2001 & 140 & 100.0 & 100.0 & 100.0 & 100.0 & 100.0 & 29.1 \\
\hline 24 & 24 APR 2002-04 FEB 2004 & 623 & 100.0 & 100.0 & 100.0 & 100.0 & 100.0 & 33.8 \\
\hline 25 & 21 MAR 2004-13 NOV 2004 & 239 & 95.1 & 98.2 & 95.6 & 98.0 & 98.7 & 13.3 \\
\hline 26 & 24 MAY 2005-20 DEC 2006 & 576 & 100.0 & 100.0 & 100.0 & 100.0 & 100.0 & 24.5 \\
\hline 27 & 01 MAY 2007-18 JAN 2008 & 263 & 100.0 & 100.0 & 100.0 & 100.0 & 100.0 & 13.6 \\
\hline 28 & 20 MAY 2008-26 JAN 2009 & 253 & 100.0 & 100.0 & 100.0 & 100.0 & 100.0 & 19.7 \\
\hline 29 & 22 APR 2009-01 MAR 2010 & 314 & 100.0 & 100.0 & 100.0 & 100.0 & 100.0 & 14.5 \\
\hline 30 & 06 JUL 2010-01 SEP 2010 & 58 & 35.5 & 51.8 & 38.8 & 60.5 & 63.8 & 4.4 \\
\hline 31 & 20 MAY 2011-25 DEC 2011 & 220 & 83.5 & 88.9 & 88.9 & 89.6 & 89.2 & 13.5 \\
\hline 32 & 28 JAN 2012-24 FEB 2012 & 28 & 74.6 & 85.7 & 74.9 & 89.5 & 90.0 & 12.5 \\
\hline 33 & 10 MAY 2012-03 NOV 2012 & 179 & 85.8 & 90.9 & 94.6 & 90.3 & 90.0 & 14.8 \\
\hline 34 & 16 JUN 2013-19 SEP 2013 & 96 & 95.9 & 92.3 & 88.6 & 92.9 & 92.2 & 23.7 \\
\hline 35 & 14 MAY 2014-31 OCT 2014 & 171 & 100.0 & 100.0 & 100.0 & 100.0 & 100.0 & 25.8 \\
\hline
\end{tabular}

Symbols: $\mathrm{D}_{\mathrm{t}}$ - drought duration (in days); DRI - drought range index (in \%); DDI - drought development index (in \%) based on: Z - catchment division into zones along the course of the main river (the first approach), $\mathrm{S}$ - Strahler stream order classification (the second approach), $\mathrm{C}-\mathrm{sub}$-catchment delimitation (the third approach), B - increase of the river basin (the fourth approach); DSI - drought severity index (in \%). 
contribution distribution are observed in all approaches. Methods based on the sub-catchment delimitation and the increase of river basin area present the highest similarity of drought contribution. Slight differences of the DRI course seem to be the result of the different size of spatial elementary units taken for estimation. Graphs related to the zones and stream network hierarchy approaches are less varied due to the higher level of spatial unit generalization. However, it is worth noting their different courses in the beginning (headwaters) part. In the first approach, with the arbitrarily adopted hydrographic junctions, the resultant sum of the drought streamflow deficit is assessed in the part of catchment, whereas, in the second approach the alimentation zones are recomposed according to hierarchical level of flow initiation. This indirectly indicates an increase in the quantity of catchment resources as well as a potential improvement of system resistance to the development of hydrological drought. Moreover, the delimited spatial units are characterized by different value of density lake index and main hydrological functions of particular reservoirs (Figs 1 and 6). Application of these characteristics to research of spatial development of hydrological drought may significantly improve the range of information received from hydrological, limnological and ecological analyses. Furthermore, it can be useful for the optimization of water management systems operating in lake catchments.

Graphs of cumulative increase of drought contribution reflect the level of drought development in the study area. In the event from 1985, an increase in the cumulative values of drought contribution are observed in the three approaches based on the catchment division into zones, sub-catchments and the increase of the river basin area as well (Fig. 12). Such a course of droughts is related to the place of their occurrence.
Graphs of drought from 1985 are increased due to its appearance in the lower and middle parts of the studied catchment, while the decreasing graphs of droughts from 1987 and 2012 are the effects of their occurrence in the upper part of the Biebrza river catchment. Due to the growth of the catchment resources in its lower part and also the better catchment resistance to the occurrence of streamflow deficits, the degree of hydrological drought development is significantly lower in 1985 than in 1987 and 2012. Furthermore, a higher variability of the course of contribution (greater slope of graph line) for these approaches is observed for the events from 1985 and 1987. Hydrological drought from 2012 occurred partly in the upper and middle fragments of the catchment. Significant drought contribution in various parts of the catchment makes the drought contribution course less changeable.

The development of hydrological drought for the approach based on Strahler's stream order classification looks completely opposite. This because of the different character of this method. A significant contribution of drought from 1985 is observed in the catchments of low number of stream order. They usually flow periodically based on surface and subsurface flow alimentation, which makes their catchments more prone to drought development. Moving downstream, droughts develop according to the stream network hierarchy, however, cumulative drought contributions are smaller for catchments of higher order streams. These reaches of streams often have hydraulic contact with several groundwater levels which increase the stability of water resources, and as a result, their catchments are more resistant to the occurrence of water shortages. Hydrological drought from 1987 developed in catchments of different numbers of stream order and therefore the course of the graph line is more even. In turn, the increasing
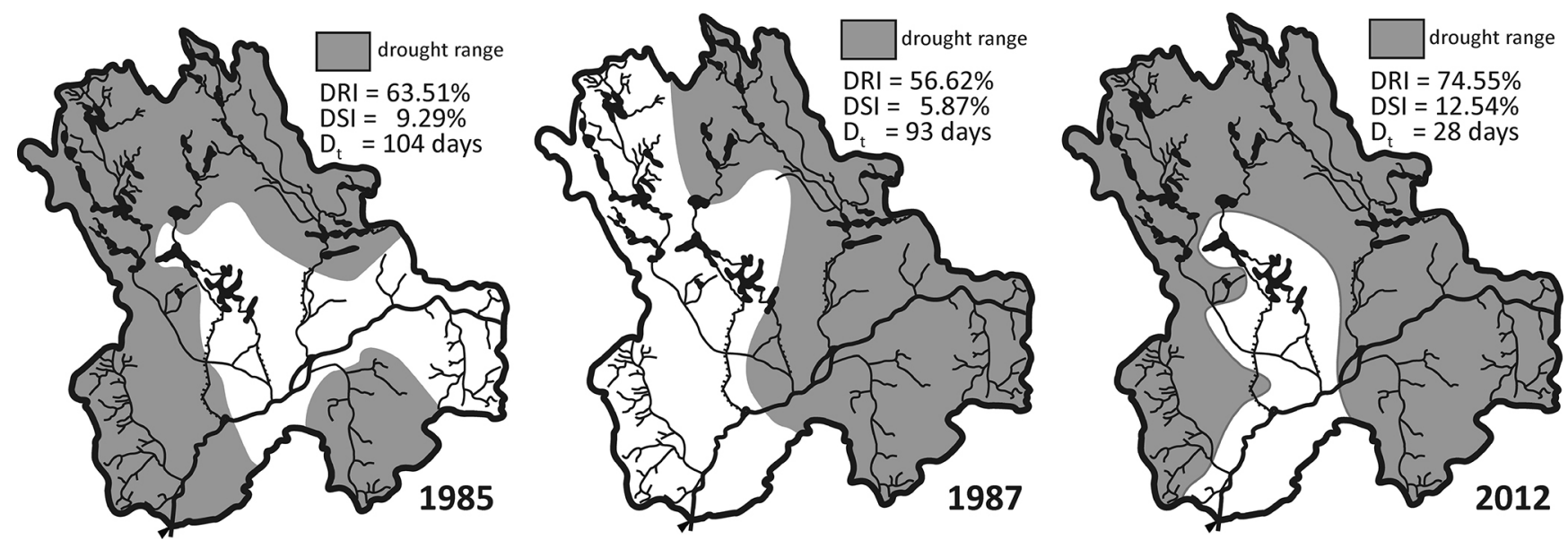

Fig. 11. Spatial range of selected hydrological droughts in the Biebrza river basin Symbols used: DRI - Drought Range Index, DSI - Drought Severity Index, $\mathrm{D}_{\mathrm{t}}$ - Drought Duration 
First approach: catchment division into zones along the course of main river
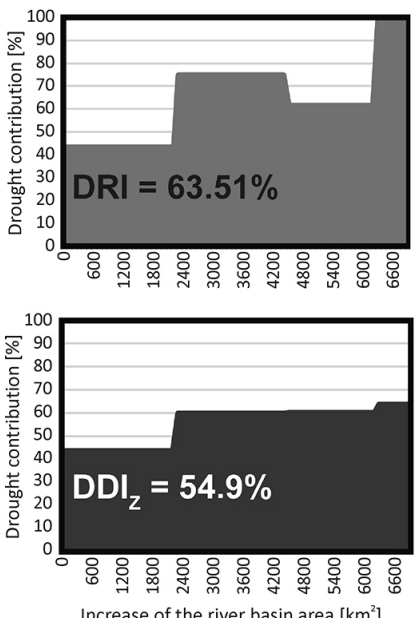

increase of the river basin area [ $\left.\mathrm{km}^{2}\right]$
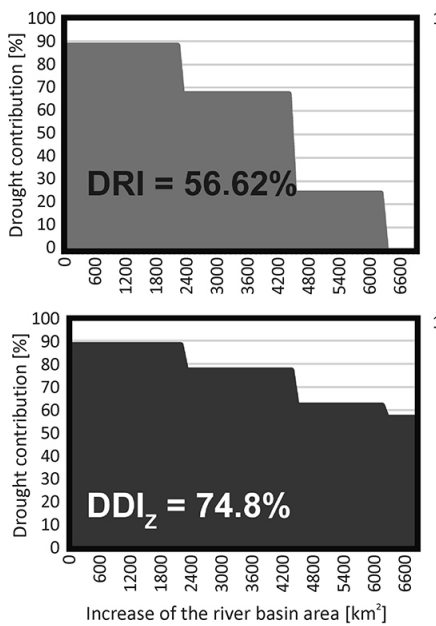

\section{Second approach: \\ Strahler's stream order classification}
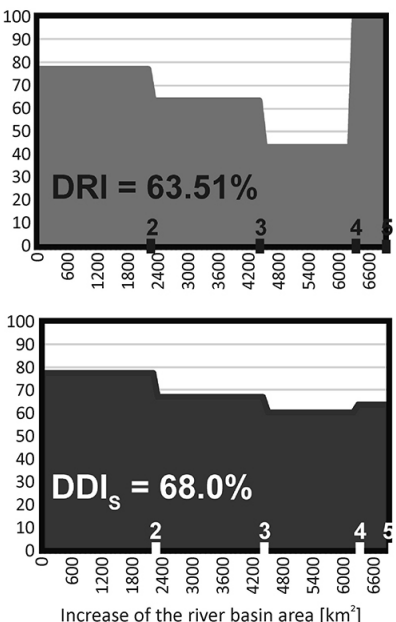

Third approach:

subcatchment

classification

1985
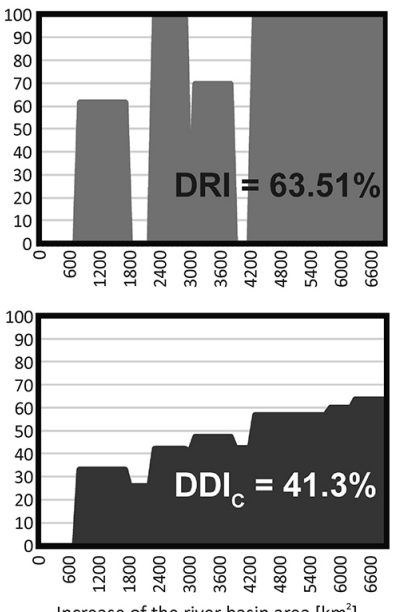

Increase of the river basin area $\left[\mathrm{km}^{2}\right]$

1987
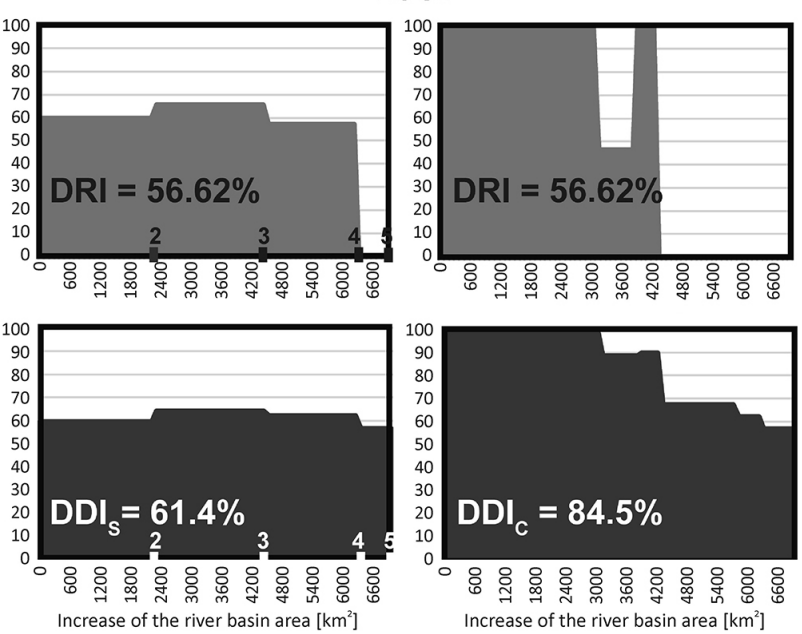

2012
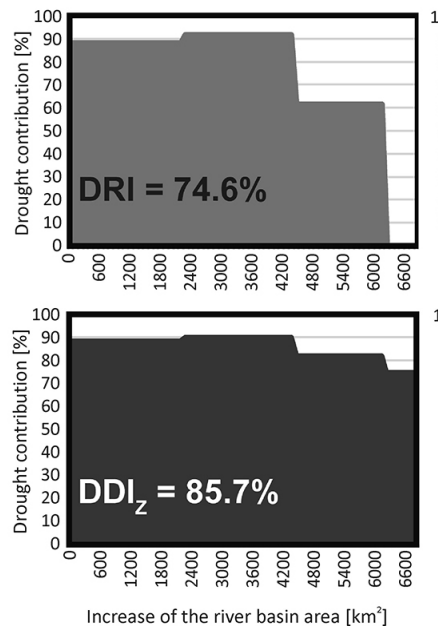
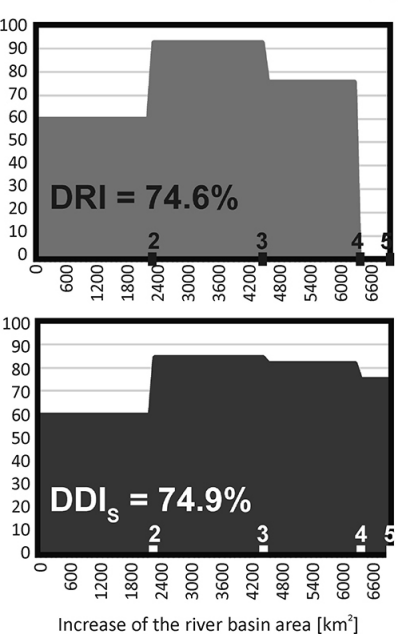
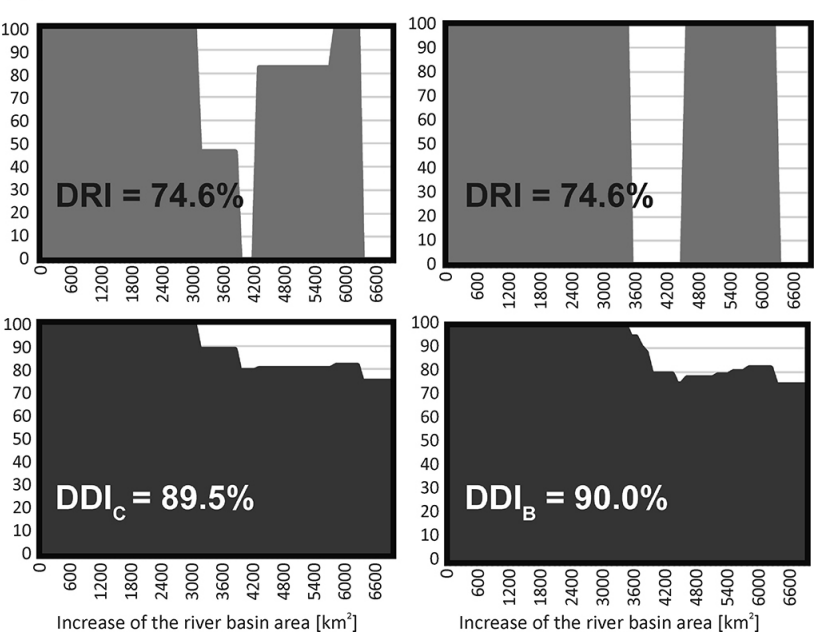

Fourth approach:

increase of river

basin area
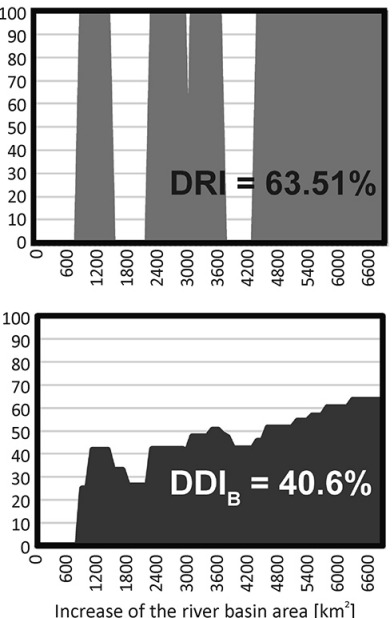
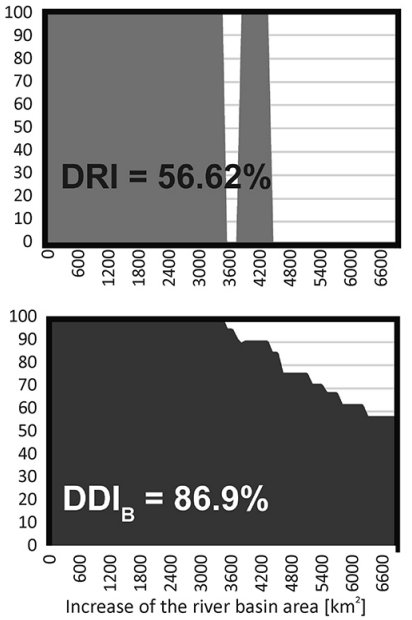

Fig. 12. Development of hydrological droughts in the Biebrza river basin in 1985, 1987 and 2012

DRI - Drought Range Index, DDI - Drought Development Index based on (subscripts): Z - basin division into zones along the main river, $S$ - basin division into Strahler's catchments (2, 3, 4, 5 - catchment order), C - basin division into sub-catchments, B - increase of the river basin area. 
line of the graph for the drought of 2012 is the result of its greater contribution in the catchments of high order streams.

The comparative analysis of selected droughts proved that three of the proposed approaches of spatial development are quite similar - approaches based on catchment zones, sub-catchments and increase of the river basin area. Different results were obtained for the method founded on Sthraler's stream network hierarchy which seems to provide some new information. Unlike the drought whose contribution in the other approaches increases with the progression of the catchment area, in this method it decreases, and vice versa. Moreover, the highest value of $\mathrm{DDI}_{S}$ is observed for the drought from 1985, whereas its value is the lowest in the other approaches.

When analysing the DDI index for selected droughts, one can notice the significant impact of the part of the catchment (covered by drought) on its development. Similar DDI values characterize the droughts which covered the upper part of the Biebrza river catchment (1987 and 2012), while the DDI values for droughts developed in the lower part (1985) are different (Fig. 13). Furthermore, for the same reason, the increase of $\mathrm{DDI}_{Z}$, $\mathrm{DDI}_{\mathrm{C}}$ and $\mathrm{DDI}_{\mathrm{B}}$ is noticed in subsequent years. Once again, a completely different specificity is observed from the approach based on Strahler's stream order classification. The $\mathrm{DDI}_{\mathrm{S}}$ values are higher if droughts cover the headwater catchments and it does not matter whether they occurred in the lower or upper part of the catchment. There are no clear relations between DDI and DRI. This proves that the level of drought development will be mainly dependent on the part of the catchment in which the phenomenon occurred and on present hydrometeorological conditions, whereas the size of area covered by drought seems to be insignificant

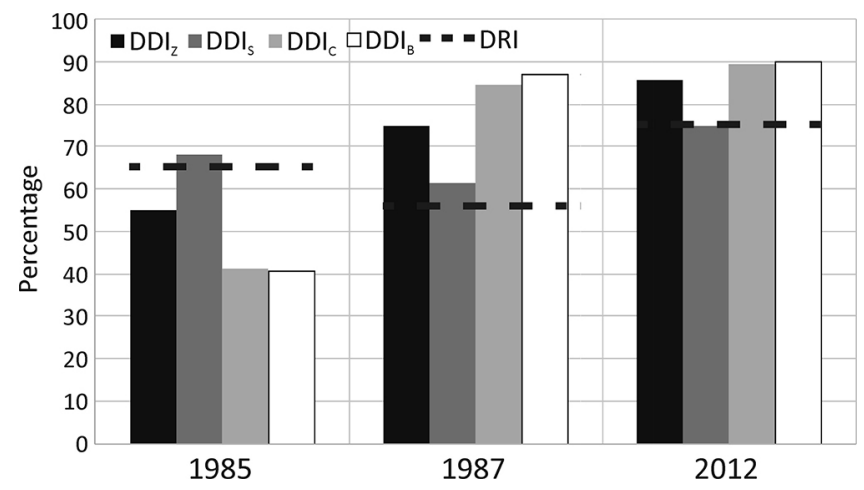

Fig. 13. Drought range and drought development indices for selected hydrological droughts in the Biebrza river basin

DRI - Drought Range Index; DDI - Drought Development Index based on (subscripts): $\mathrm{Z}$ - the basin division into zones along the main river, $\mathrm{S}$ - basin division into Strahler's catchments, $\mathrm{C}$ - basin division into the sub-catchments, $\mathrm{B}$ - increase of the river basin area. in this respect. The greatest significance in the group of determinants of hydrological drought progression will be the size (discharge) of the river where the shortages are observed and its location in the hydrological structure as well as the capacity and dynamics of the groundwater reservoirs and the presence of lakes with river inflow and outflow which have a hydraulic connection with ground waters.

Throughout the whole investigated period, the intensity and range of hydrological droughts is characterized by significant differentiation (Fig. 14). The mean duration of the water shortage period was estimated at 212 days, however, the longest drought lasted almost 2 years between 2002 and 2004 (Table 2). Even though the length of the shortest drought was only 22 days, all observed episodes occurred very regularly during the multi-year period. This might be a result of the influence of lake regimes on river flow regime. It is determined by additional lake basin retention capacity which on one hand may prevent severe hydrological drought development but on the other hand causes the appearance of systematic renewal resources periods as middle low flow episodes. It is worth noting that in lowland catchments without lakes in river systems, hydrological drought occurrence and duration is much more diversified (Kozek and Tomaszewski 2018).

The average range of hydrological drought in the studied catchment amounted to $89 \%$, which means that droughts mostly covered almost the entire Biebrza river catchment. This characteristic ranged from 26 to $100 \%$ but it should be remembered that an assumption was made that only droughts with a range index of over $20 \%$ were taken into consideration (Table 2 ). The high number of episodes reaching $100 \%$ in range (21 of 35) indicates that typically the entire catchment area $(6,900$ $\mathrm{km}^{2}$ ) is covered by drought. Events with partial cover are grouped in two wet periods only: mid 1980s and the beginning of the 2010s (Fig. 14).

The severity of hydrological drought in the investigated area ranged from 1.5 to $40.4 \%$ with an average on the level of $20 \%$ (Table 2). The highest drought intensity occurred in the first half of the 1990 s. (DSI $=40.4 \%$ and $36.7 \%)$ and at the beginning of the 2000s. (33.8\%) - Fig. 14. Both mentioned periods are indicated as seriously dry from the meteorological and hydrological point of view in the scale of the whole country (Stachy 2011; Tomaszewski 2012). Mild hydrological droughts are connected with not fully ranged episodes. They are also characterized by a different pattern of spatial drought progression. In the mid1980s all the drought development indices were very similar, whereas in 1988 and at the beginning of the 2010s indices based on catchment division into zones along the course of the main river $\left(\mathrm{DDI}_{\mathrm{Z}}\right)$ and Strahler's stream order classification $\left(\mathrm{DDI}_{\mathrm{S}}\right)$ 


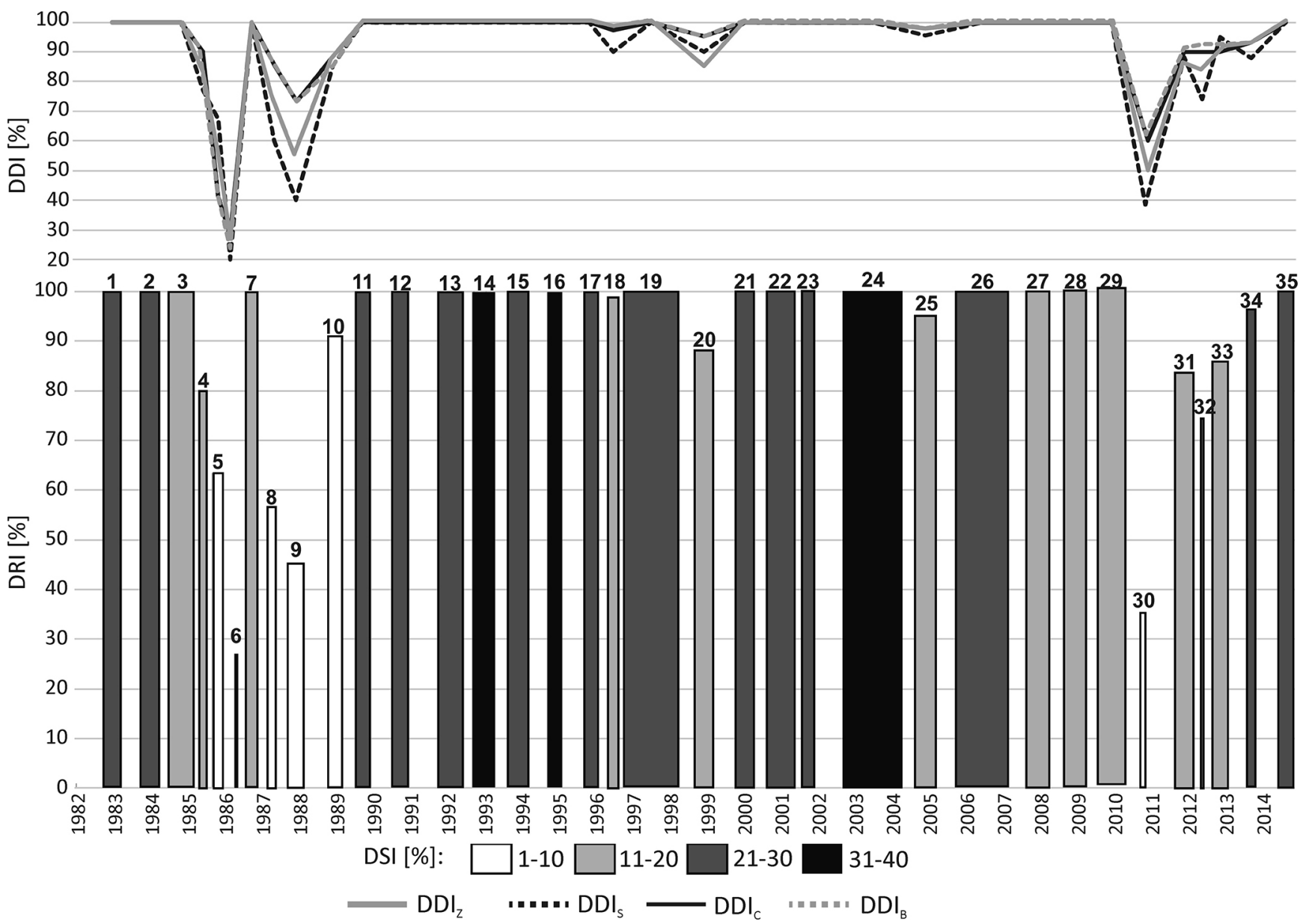

Fig. 14. Range, severity and development of hydrological drought events in the Biebrza river basin between 1982 and 2014 . Symbol explanations in Table 2

were significantly lower than the others. This indicates that a similar severity and range cover of hydrological drought might develop in different spatial directions which may cause various reactions in the hydrological system to water shortages and regime of lakes.

\section{Conclusions}

The research that has been carried out proved that spatial progression of hydrological drought in lake catchments is characterized by varying intensity, duration and spatial direction of development. The introduction of drought progression indices as estimators of spatial drought development has broadened significantly the scope of analyses based on the drought range index. There were 4 approaches that reflected a different spatial order of drought development according to the ordering of streams and their catchments, partial catchments as well as basin area increase. Analysis of estimated indices and graph shapes allowed stream position in the catchment hydrological structure to be valorised in terms of vulnerability to drought development. Moreover, identi- fied space units were characterized by different values of density lake index and the main hydrological functions of lakes which may significantly expand hydrological, limnological and ecological analyses of water shortage. It could also offer support for the optimization of water management systems in river-lake catchments.

Comparative analysis indicated a high similarity in the results obtained from 3 approaches based on zones, sub-catchments and basin area increase. They allowed the direction and dynamics of drought development to be identified according to downstream catchment area progression. The hydrological drought development index based on sub-catchment (DDI ${ }_{C}$ ) was recommended as the most informative and simplest in terms of identification from among this group. Quite different and new information was delivered by analysis of the development index based on Sthraler's stream ordering $\left(\mathrm{DDI}_{\mathrm{s}}\right)$ which offers the possibility to assess hydrological drought progression according to hierarchically numbered streams in the whole river system. This was the second index recommended for further investigation of water shortage in lake catchments. 
Time series analysis made it possible to identify the features typical of hydrological drought progression in lake catchments over a multi-year period. They are characterized by relatively similar duration which is determined by the impact of the lake regime on river runoff regime. Moreover, the observed droughts reached a high, very often maximum range, while their severity (intensity) was rather low and determined mostly by the hydro-meteorological conditions of the preceding and developing dry period.

\section{References}

Anibas C., Vrbeiren B., Buis K., Chornański J., De Doncker L., Okruszko T., Meire P., Batelaan O., 2012, A hierarchical approach on groundwater-surface water interaction in wetlands along the upper Biebrza River, Poland, Hydrol. Earth Syst. Sci. 16: 2329-2346.

Bajkiewicz-Grabowska E., 2002, Obieg materii w systemach rzeczno-jeziornych (Circulation of matter in the riverlake systems), Wydaw UW, Warszawa, 274 pp. (in Polish, English summary)

Bartnik A., 2005, Odpływ niski w Polsce (Low-flow in Poland), Acta Geogr. Lodz. 91: 1-95. (in Polish, English summary)

Batelaan O., Kuntohadi T., 2002, Development and Application of a Groundwater Model for the Upper Biebrza River Basin, Annals of Warsaw Agricultural University SGGW. Land Reclamation 33: 57-69.

Byczkowski A., Fal B., 2004, Wody powierzchniowe (Surface water), [in:] Banaszuk H. (ed.), Kotlina Biebrzańska i Biebrzański Park Narodowy. Aktualny stan, walory, zagrożenia i potrzeby czynnej ochrony środowiska. Monografia Przyrodnicza (The Biebrza Valley and the Biebrza National Park. Biological monograph), Wydaw. Ekonomia i Środowisko, Białystok: 113-167. (in Polish)

Dębski K.,1970, Hydrologia (Hydrology), Arkady, Warszawa, 368 pp. (in Polish)

Dynowska I., 1994, Reżim odpływu rzecznego. Plansza 32.3: Odpływ rzeczny (River runoff regime. Sheet 32.3: River runoff), [in:] IGiPZ PAN (ed.), Atlas Rzeczypospolitej Polskiej (Atlas of the Republic of Poland), Główny Geodeta Kraju, Warszawa. (in Polish)

Hisdal H., Stahl K., Tallaksen L. M., Demuth S., 2001, Have streamflow droughts in Europe become more severe or frequent?, Int. J. Climatol. 21(3): 317-333.

Hisdal H., Tallaksen L.M., Clausen B., Peters E., Gustard A., 2004, Hydrological Drought Characteristics, [in:] Tallaksen L.M., van Lanen H.A.J. (eds), Hydrological Drought. Processes and estimation methods for streamflow and groundwater. Developments in Water Science Vol. 48, Elsevier, Amsterdam: 139-198.

[IMGW] Instytut Meteorologii i Gospodarki Wodnej (Institute of Meteorology and Water Management), 1983, Podział Hydrograficzny Polski. Część I: Zestawienia liczbowo-opisowe (Hydrographical Division of Poland. Part
I: Numerical and descriptive summary tables), Wydaw. KiŁ, Warszawa. (in Polish)

Jokiel P., 1994, Zasoby, odpływ i odnawialność wód podziemnych strefy aktywnej wymiany w Polsce (Groundwater resources, renewability and runoff in the zone of active exchange in Poland), Acta Geogr. Lodz. 66-67: 1-236 pp. (in Polish)

Jóźwiak K, Filar S., Nidental M., Węglarz D., Przytuła E., 2019, Zróżnicowanie tła hydrogeochemicznego wód podziemnych eksploatowanych w zlewni Biebrzy (Diversity of the hydrogeochemical background of groundwater exploited in the Biebrza catchment), Biul. PIG 475: 75-84. (in Polish, English summary)

Kaznowska E., 2006, Charakterystyka susz hydrologicznych na przykładzie wybranych rzek północno-wschodniej części Polski (The characteristics of hydrological droughts based on the example of selected rivers in the north eastern part of Poland), Infrastruktura i ekologia terenów wiejskich 4(2): 51-59 (in Polish, English summary)

Kaznowska E., 2012, Wieloletnie tendencje w kształtowaniu się wybranych charakterystyk niżówek w zlewni rzeki Zagożdżonki (Long-term trend of shaping selected characteristics of streamflow droughts in the Zagożdżonka catchment), Infrastruktura i ekologia terenów wiejskich, 3(4): 215-227. (in Polish, English summary)

Kozek M., Tomaszewski E., 2018, Selected characteristics of hydrological drought progression in the upper Warta river catchment, Acta Sci. Pol. Formatio Circumiectus 17(3): 77-87.

Mioduszewski W., Ślesicka A., Querner E., 2004, Warunki zasilania doliny dolnej Biebrzy (Conditions of recharge in the lower Biebrza Valley), Woda-Środowisko-Obszary Wiejskie 4(1): 67-78. (in Polish, English summary)

Ozga-Zielińska M., 1990, Niżówki i wezbrania - ich definiowanie i modelowanie (Droughts and floods - Their definition and modeling), Przegl. Geof. 35(1-2): 33-44. (in Polish, English summary)

Smakhtin V.U., 2001, Low flow hydrology: a review, J. Hydrol. 240(3-4): 147-186.

Stachý J., 2011, Występowanie lat mokrych i posusznych w Polsce, 1951-2008 (Wet and dry years occurrence in Poland, 1951-2008), Gosp. Wodna 8: 313-321. (in Polish)

Strahler A.N., 1964, Quantitative geomorphology of drainage basin and channel networks, [in:] Choe V.T. (ed.), Handbook of applied hydrology, Mc Graw-Hill, New York: 439-476.

Strzebońska-Ratomska B., 1994, Metodyka oceny intensywności i zasięgu suszy hydrologicznej. cz. I: Susza hydrologiczna na Podkarpaciu w latach 1961-1990 (Methodology of the evaluation of intensity and range of hydrological drought. P. Hydrological drought in the Carpathian Region during 1961-1990), Wiad. IMGW 4: 15-42. (in Polish, English summary) 
Tokarczyk T., 2013, Classification of low flow and hydrological drought for a river basin, Acta Geophys. 61(2): 404421.

Tomaszewski E., 2011, Defining the threshold level of hydrological drought in lake catchments, Limnol. Rev. 11(2): 81-89.

Tomaszewski E., 2012, Wieloletnia i sezonowa dynamika niżówek w rzekach środkowej Polski (Multiannual and sea- sonal dynamics of low flows in rivers of central Poland), Wydaw. UŁ, Łódź, 265 pp. (in Polish, English summary)

Wassen M.J., 1992, Hydro-ecological analysis of the Biebrza mire (Poland), Wetl. Ecol. Manag. 2(3): 119-139.

Yevjevich, V., 1967, An objective approach to definitions and investigations of continental hydrologic drought. Hydrology Paper 23, Colorado State University, Fort Collins, 18 pp. 